\title{
Knowledge and Expectations of Perinatal Care Among Pregnant Women During the COVID-19 Pandemic
}

\author{
Caleb Chun Wei Lim \\ KK Women's \& Children's Hospital \\ Marlene Samantha Sze Minn Goh \\ KK Women's \& Children's Hospital \\ Ka-Hee Chua \\ KK Women's \& Children's Hospital \\ Meei Jiun Seet \\ KK Women's \& Children's Hospital \\ Siew Guek Tay \\ KK Women's \& Children's Hospital \\ Manisha Mathur \\ KK Women's \& Children's Hospital \\ Juin Yee Kong \\ KK Women's \& Children's Hospital
}

Kee Thai Yeo ( $\square$ yeo.kee.thai@singhealth.com.sg)

KK Women's \& Children's Hospital

\section{Research Article}

Keywords: COVID-19, pregnancy, neonatal, labor, breastfeeding, telemedicine, delivery, maternal-fetal infection transmission

Posted Date: March 19th, 2021

DOl: https://doi.org/10.21203/rs.3.rs-285815/v1

License: (1) This work is licensed under a Creative Commons Attribution 4.0 International License. Read Full License 


\section{Abstract}

Background: This study aimed to investigate the knowledge and expectations of pregnant women on perinatal and neonatal care during the coronavirus disease 2019 (COVID-19) pandemic in Singapore.

Methods: A cross-sectional survey was administered to pregnant women attending antenatal clinics between August and September 2020 via a secure online platform. Participants aged $\geq 21$ years without a history of confirmed COVID-19 were included. The survey consisted of 10 questions which evaluated the knowledge and expectations on perinatal and neonatal care during the current pandemic.

Results: A total of 313 pregnant women completed the survey. The mean age of the participants was 30 years (SD 4; range 22-43 years). The median gestational age was 25 weeks (range 4-40 weeks). The participants were predominantly multiparous (54\%) and almost all $(98 \%)$ had completed secondary level education. Majority of participants were aware of the spread of COVID-19 by respiratory secretions and contact (90\%), and the importance of prevention strategies (94\%). Up to $72 \%$ agreed or strongly agreed that in-utero transmission of SARS-CoV-2 was possible. Most were unsure of the optimal mode of delivery (77\%) and only $22 \%$ believed that breastfeeding was safe in a pregnant woman with active COVID-19. There was no significant association between the sociodemographic factors evaluated and maternal agreement with the possibility of in-utero SARS-CoV-2 transmission and the risk associated with vaginal delivery in women with COVID-19. Although $46 \%$ of participants were concerned about the increased risk of contracting COVID-19 during routine clinic appointments, only $37 \%$ of the cohort were agreeable with teleconferencing of clinic appointments. More than half (56\%) of the participants reported that their postnatal confinement plans were affected by the current pandemic.

Conclusions: Our survey revealed that majority of participants were aware of modes of transmission, prevention strategies and in utero transmission of SARS-CoV-2. Significant gaps were identified in their knowledge related to method of delivery and safety of breastfeeding, along with significant variability to the agreement with alterations to the perinatal care. For best practice we recommend provision of evidence-based information early to expectant mothers by the healthcare professionals to reduce misinformation and anxiety amongst pregnant women.

\section{Background}

As of January 2021, the coronavirus disease 2019 (COVID-19) pandemic, caused by the severe acute respiratory syndrome coronavirus 2 (SARS-CoV-2) virus, has infected more than 100 million people worldwide with more than 2 million deaths[1]. Based on current projections, the current pandemic is expected to last beyond 2021, with the number of infected cases still on the rise and countries experiencing second or third waves of COVID-19 infections[2]. Emerging data surrounding vulnerable populations indicate that pregnant women appear to have an increased risk of severe respiratory disease and are more likely to need intensive care treatment for COVID-19 as compared to non-pregnant women of reproductive age [3, 4]. Cases of severe SARS-CoV-2 infections have also been reported in neonates with significant gastrointestinal, respiratory and neurological manifestations [5].

Due to the rapidly accumulating medical knowledge, clinical practice guidelines issued by national and professional bodies regarding COVID-19 and pregnancy have been rapidly evolving. These include recommendations regarding prevention of SARS-CoV-2 transmission from mother to infant during the antenatal and perinatal period. In the initial stages of the pandemic, most recommendations were based on expert consensus, and were of variable, low methodological rigor [6-8]. As the pandemic continues to evolve, there are still remaining uncertainty about the risk and impact of COVID-19 on perinatal care. With this underlying uncertainty surrounding the care of motherinfant during this current pandemic, we explored the knowledge, concerns and expectations of pregnant women about the impact of COVID-19 on perinatal care.

\section{Methods}

\section{Study design and setting}

This is a cross-sectional survey conducted among pregnant women attending the Specialist Obstetrics Outpatient Clinics at KK Women's and Children's Hospital (KKH), Singapore, from Aug 1, 2020 to Sept 31, 2020. KKH is an 830-bed referral hospital that cares for $>11,500$ pregnant women annually. Pregnant women aged $\geq 21$ years old with no previous COVID-19 were eligible for the study. Eligible and willing participants were directed to fill in the survey which was hosted on a secure online platform (FormSG, GovTech, Singapore). They were given access to the survey via a quick-response (QR) code. All responses were obtained anonymously and participants had to provide answers for all the questions to complete the survey. 
The online survey consisted of a set of 10 questions which were formulated based on a literature review of published international and local perinatal COVID-19 guidelines [9-13] and in consultation with local obstetricians and neonatologists. The questions assessed pregnant women's knowledge regarding the modes of transmission and methods of prevention of COVID-19, as well as elicited their opinions and expectation regarding the possibility of in utero infection, optimal mode of delivery, safety of breastfeeding and

teleconferencing of routine clinic visits during the current COVID-19 pandemic (Supplemental Table 1). The survey included demographic and pregnancy-related data from the participants. Majority of the survey utilised a Likert Scale (e.g. "Strongly Disagree, Disagree, Neutral, Agree and Strongly Agree") to measure the participants' attitudes and opinions to the statements.

Demographic and responses to the survey were described and compared across the cohort. Multivariate analysis was performed to assess the association between demographic characteristics and opinions and the various aspects of perinatal care investigated. Adjusted odds ratios (AOR)

were expressed with $95 \%$ confidence intervals (Cls). Statistical significance was set at $\mathrm{P}<0.05$, using a 2-tailed comparison. Data was analyzed using SPSS Statistics software, version 23.0 (IBM, Armonk, New York).

Ethics approval and waiver of consent was obtained from the SingHealth Centralised Institutional Review Board (Ref No. 2020/2648).

\section{Results}

\section{Study Cohort}

A total of 313 pregnant women took part in the survey during the study period. The mean age of women who participated in the survey was aged 30 years (SD 4), with a range from 22 to 43 years old. The racial distribution of our study cohort is as follows: Chinese (54\%), Malay (32\%), Indian (7\%) (Table 1). The median gestational age of the pregnant women at survey participation was 25 weeks (range $4-$ 40 weeks). The participants were mostly multiparous (54\%) and almost all $(98 \%)$ had completed secondary level education. Around $49 \%$ of the cohort reported an annual household income > 30,000 SGD, with 17\% unemployed at the time of the survey. 
Table 1

Clinical Characteristics of Survey Participants

\begin{tabular}{|c|c|}
\hline Demographics & $\begin{array}{l}\text { Total (\%) } \\
\mathrm{n}=\mathbf{3 1 3}\end{array}$ \\
\hline Age group, years, $n(\%)$ & $245(78.3 \%)$ \\
\hline $21-34$ & $68(21.7 \%)$ \\
\hline \multicolumn{2}{|l|}{35 and above } \\
\hline Parity, n (\%) & $146(46.6)$ \\
\hline 0 & $98(31.3)$ \\
\hline 1 & $49(15.7)$ \\
\hline 2 & $16(5.1)$ \\
\hline 3 & $4(1.3)$ \\
\hline \multicolumn{2}{|l|}{4} \\
\hline Race, n (\%) & $167(53.4)$ \\
\hline Chinese & $105(33.5)$ \\
\hline Malay & $21(6.7)$ \\
\hline Indian & $20(6.4)$ \\
\hline \multicolumn{2}{|l|}{ Others } \\
\hline Trimester, n (\%) & $40(12.8)$ \\
\hline $1 \mathrm{st}$ & $132(42.1)$ \\
\hline 2nd & $141(45.0)$ \\
\hline \multicolumn{2}{|l|}{$3 r d$} \\
\hline Education level, $n$ (\%) & $6(2.0)$ \\
\hline No formal education/Primary level & $46(14.7)$ \\
\hline Secondary level (GCE N level/GCE O level) & $123(39.3)$ \\
\hline Post-Secondary level (GCE A level/Diploma/ITE) & $78(24.9)$ \\
\hline Undergraduate & $60(19.1)$ \\
\hline \multicolumn{2}{|l|}{ Postgraduate } \\
\hline Average Household Income, n (\%) & $55(17.6)$ \\
\hline Unemployed & $42(13.4)$ \\
\hline$\leq \operatorname{SGD} 10,000$ & $63(20.1)$ \\
\hline SGD $10,001-30,000$ & $70(22.4)$ \\
\hline SGD $30,001-50,000$ & $35(11.2)$ \\
\hline SGD $50,001-80,000$ & $48(15.3)$ \\
\hline$\geq$ SGD 80,001 & \\
\hline
\end{tabular}

\section{Participants Responses to Survey Questions}

The breakdown of responses to questions regarding knowledge, understanding and expectations of perinatal and neonatal care is summarized in Tables 2 and 3 respectively. 
Table 2

Knowledge and Understanding of Perinatal and Neonatal Care During the Current COVID-19 Pandemic

\begin{tabular}{|c|c|c|}
\hline Questions & Responses & $\begin{array}{l}\text { Total } \\
\text { n (\%) }\end{array}$ \\
\hline \multirow[t]{3}{*}{$\begin{array}{l}\text { Qx. COVID-19 is mainly spread by airway secretions from infected persons and by contact with } \\
\text { these secretions }\end{array}$} & $\begin{array}{l}\text { Strongly } \\
\text { Agree/Agree }\end{array}$ & $\begin{array}{l}283 \\
(90.4)\end{array}$ \\
\hline & Neutral & $\begin{array}{l}26 \\
(8.3)\end{array}$ \\
\hline & $\begin{array}{l}\text { Strongly } \\
\text { Disagree/Disagree }\end{array}$ & $4(1.3)$ \\
\hline \multirow[t]{3}{*}{ Qx. Wearing a mask and frequent hand hygiene can help to prevent the spread of COVID-19 } & $\begin{array}{l}\text { Strongly } \\
\text { Agree/Agree }\end{array}$ & $\begin{array}{l}294 \\
(93.9)\end{array}$ \\
\hline & Neutral & $\begin{array}{l}15 \\
(4.8)\end{array}$ \\
\hline & $\begin{array}{l}\text { Strongly } \\
\text { Disagree/Disagree }\end{array}$ & $4(1.3)$ \\
\hline \multirow[t]{3}{*}{$\begin{array}{l}\text { Qx. There is a risk of spreading COVID-19 to the unborn child if a pregnant woman is infected with } \\
\text { COVID }\end{array}$} & $\begin{array}{l}\text { Strongly } \\
\text { Agree/Agree }\end{array}$ & $\begin{array}{l}226 \\
(72.2)\end{array}$ \\
\hline & Neutral & $\begin{array}{l}61 \\
(19.5)\end{array}$ \\
\hline & $\begin{array}{l}\text { Strongly } \\
\text { Disagree/Disagree }\end{array}$ & $\begin{array}{l}26 \\
(8.3)\end{array}$ \\
\hline \multirow[t]{3}{*}{$\begin{array}{l}\text { Qx. For mothers with COVID-19, separation of the mother and infant after birth and for up to } 14 \\
\text { days is necessary to prevent infection of the infant }\end{array}$} & $\begin{array}{l}\text { Strongly } \\
\text { Agree/Agree }\end{array}$ & $\begin{array}{l}169 \\
(54.0)\end{array}$ \\
\hline & Neutral & $\begin{array}{l}94 \\
(30.0)\end{array}$ \\
\hline & $\begin{array}{l}\text { Strongly } \\
\text { Disagree/Disagree }\end{array}$ & $\begin{array}{l}50 \\
(16.0)\end{array}$ \\
\hline \multirow[t]{3}{*}{ Qx. It is safe for women with COVID-19 to deliver their baby via } & $\begin{array}{l}\text { Normal vaginal } \\
\text { delivery }\end{array}$ & $\begin{array}{l}53 \\
(16.9)\end{array}$ \\
\hline & Caesarean section & $\begin{array}{l}20 \\
(6.4)\end{array}$ \\
\hline & Unsure & $\begin{array}{l}240 \\
(76.7)\end{array}$ \\
\hline \multirow{3}{*}{$\begin{array}{l}\text { Qx. } \\
\text { Breastfeeding in mothers with COVID-19 is }\end{array}$} & $\begin{array}{l}\text { Safe and should be } \\
\text { encouraged }\end{array}$ & $\begin{array}{l}70 \\
(22.4)\end{array}$ \\
\hline & $\begin{array}{l}\text { Risky and should be } \\
\text { avoided }\end{array}$ & $\begin{array}{l}77 \\
(24.6)\end{array}$ \\
\hline & Unsure & $\begin{array}{l}166 \\
(53.0)\end{array}$ \\
\hline
\end{tabular}




\begin{tabular}{|c|c|c|}
\hline Questions & Responses & $\begin{array}{l}\text { Total } \\
\text { n, (\%) }\end{array}$ \\
\hline \multirow[t]{3}{*}{$\begin{array}{l}\text { Qx. I am worried about the risk of contracting COVID-19 when I come to hospital for my routine check- } \\
\text { ups and delivery }\end{array}$} & $\begin{array}{l}\text { Strongly } \\
\text { Agree/Agree }\end{array}$ & $\begin{array}{l}146 \\
(46.6)\end{array}$ \\
\hline & Neutral & $\begin{array}{l}108 \\
(34.5)\end{array}$ \\
\hline & $\begin{array}{l}\text { Strongly } \\
\text { Disagree/Disagree }\end{array}$ & $\begin{array}{l}59 \\
(18.9)\end{array}$ \\
\hline \multirow[t]{3}{*}{$\begin{array}{l}\text { Qx. I would be open to the idea of teleconferencing my clinic appointments to minimise the physical } \\
\text { visits to the hospital }\end{array}$} & $\begin{array}{l}\text { Strongly } \\
\text { Agree/Agree }\end{array}$ & $\begin{array}{l}117 \\
(37.4)\end{array}$ \\
\hline & Neutral & $\begin{array}{l}108 \\
(34.5)\end{array}$ \\
\hline & $\begin{array}{l}\text { Strongly } \\
\text { Disagree/Disagree }\end{array}$ & $\begin{array}{l}88 \\
(28.1)\end{array}$ \\
\hline \multirow[t]{4}{*}{$\begin{array}{l}\text { Qx. I would accept restriction of visitors during the labour, delivery and postnatal stay due to the COVID } \\
19 \text { situation }\end{array}$} & $\begin{array}{l}\text { Strongly } \\
\text { Agree/Agree }\end{array}$ & $\begin{array}{l}185 \\
(59.1)\end{array}$ \\
\hline & Neutral & 72 \\
\hline & $\begin{array}{l}\text { Strongly } \\
\text { Disagre/Dicagree }\end{array}$ & \\
\hline & & $\begin{array}{l}56 \\
(17.9)\end{array}$ \\
\hline \multirow[t]{3}{*}{$\begin{array}{l}\text { Qx. My plans for confinement practices will be affected/have been affected by restrictions and } \\
\text { hygiene recommendations during the current COVID- } 19 \text { situation }\end{array}$} & $\begin{array}{l}\text { Strongly } \\
\text { Agree/Agree }\end{array}$ & $\begin{array}{l}177 \\
(56.5)\end{array}$ \\
\hline & Neutral & $\begin{array}{l}93 \\
(29.7)\end{array}$ \\
\hline & $\begin{array}{l}\text { Strongly } \\
\text { Disagree/Disagree }\end{array}$ & $\begin{array}{l}43 \\
(13.7)\end{array}$ \\
\hline
\end{tabular}

\section{Knowledge and Understanding of Perinatal and Neonatal Care}

A. Transmission \& Prevention - A large proportion of survey participants $(90 \%)$ agreed that COVID-19 is spread predominantly by airway secretions and by contact with these secretions. Up to $94 \%$ also agreed that wearing a mask and frequent hand hygiene could prevent the spread of COVID-19.

B. Vertical transmission - Majority of pregnant women surveyed (72\%) agreed or strongly agreed that transmission of COVID-19 to the unborn fetus during pregnancy was possible. The proportion of women with this belief about possible maternal-foetal transmission was consistent regardless of parity (68.9\% multigravida and $76 \%$ of primigravida women agreed), gestation at time of survey $(70.0 \%$ of women in the first trimester, $73.7 \%$ of women in the second trimester, and $70.9 \%$ of women in the third trimester agreed), age ( $72.2 \%$ of women $<34$ years and $72.1 \%$ of women $>35$ years agreed), income levels ( $72.2 \%$ with earnings $<$ SGD 10000 and $72.3 \%$ with > SGD 50001 agreed) or education level (73.1\% educated up to secondary level and $68.3 \%$ of women with a post-secondary degree agreed).

C. Mode of delivery - The majority of survey participants (77\%) were unsure about the safe delivery method for pregnant women with active COVID-19. Up to $17 \%$ of the participants believed that normal vaginal delivery was a safe option. The proportion of women with uncertainty regarding safe delivery method in the context of COVID-19 was fairly consistent when stratified by parity $(70.7 \%$ of multigravida women and $83.6 \%$ of primigravida women were unsure), gestation ( $77.5 \%$ of women in their first trimester, $77.6 \%$ of women in their second trimester and $75.2 \%$ of women in their third trimester were unsure), age $(70.6 \%$ of women $<34$ years and $78.4 \%$ of women $>35$ years were unsure), income levels ( $81.4 \%$ with earnings < SGD 10000 and $66.3 \%$ with > SGD 50001 were unsure) or education level $(76.9 \%$ of women who were educated up to secondary level and $78.9 \%$ of women who obtained a postsecondary degree were unsure).

D. Breastfeeding with COVID-19 - Slightly more than half (53\%) of the participants were unsure if it were safe for a mother with COVID19 to breastfeed. Another $24.6 \%$ of pregnant women thought that breastfeeding should be avoided altogether. Subgroup analysis 
revealed that this uncertainty surrounding breastfeeding was consistent across participants regardless of whether they were stratified by parity ( $58.9 \%$ of multigravida women and $47.9 \%$ of primigravida women were unsure), gestation ( $47.5 \%$ of women in the first trimester, $53.8 \%$ of women in the second trimester and $53.8 \%$ of women in the third trimester were unsure), age ( $51 \%$ of women $<35$ years and $60.3 \%$ of women $>35$ years were unsure), income levels ( $54.6 \%$ with earnings $<$ SGD 10000 and $57.8 \%$ with earnings $>$ SGD 50001 were unsure) or education levels ( $57.7 \%$ of women who were educated up to secondary level and $56.9 \%$ of women who obtained a post-secondary degree were unsure).

\section{Expectations of Perinatal \& Neonatal Care}

A. Concerns about hospital visit and risk of COVID-19 - The majority of respondents (46.6\%) were concerned about the risk of contracting COVID-19 at the hospital when appearing for their routine appointments or during labor. When asked about teleconferencing routine clinic appointments, around $37 \%$ of the study participants were open to the idea, whereas $28 \%$ of the study cohort disagreed. Higher proportion of women who were $>35$ years of age $(29.4 \%$ vs $27.8 \%, p=0.07)$ and those who were primigravida ( $31.5 \%$ vs $25.1 \%, p=0.1)$ rejected teleconferencing. Patients in their first trimester were more likely to be open to the idea of teleconferencing (55\%) compared to those in their second (35.3\%) and third (34.2\%), $p=0.06$ trimesters. Around $59 \%$ of survey participants also agreed or strongly agreed that restriction of visitors during the period of labour was necessary amid the COVID-19 pandemic. Even so, $18 \%$ of the participants strongly disagreed with the restriction of visitors.

B. Postnatal and Confinement practices - More than half of the pregnant women surveyed (56.5\%) agreed or strongly agreed that prevailing confinement practices would be disrupted by the COVID-19 pandemic, while $13.7 \%$ of the cohort did not perceive that their confinement practices would be affected. This expectation did not differ with parity, with $55.1 \%$ of primiparous participants and $58.2 \%$ of multiparous participants reporting that their confinement practices will be affected.

\section{Factors Affecting Knowledge and Expectation of Perinatal and Neonatal Care}

The associations between sociodemographic factors and maternal understanding and expectations of perinatal and neonatal care during the current pandemic are shown in Table 4. There was no significant association between the sociodemographic factors evaluated and maternal agreement with the possibility of in-utero transmission of COVID-19 and the risk of vaginal delivery in mothers with COVID-19. Maternal age $>35$ years was significantly associated with agreement with separation of mother-infant after birth [AOR $1.89(95 \% \mathrm{Cl} 1.05$, 3.39)], restriction of visitors during postnatal period [1.92 $(1.05,3.49)]$ and that their confinement practices were affected $[2.3(1.26,4.17)]$. Pregnant women who were multigravidas disagreed or strongly disagreed that breastfeeding was safe in women with active COVID-19 $[0.42(0.23,0.75)]$. 
Table 4

Multivariable Analysis of Factors Affecting Pregnant Women's Understanding and Expectations of Perinatal and Neonatal Care

\begin{tabular}{|c|c|c|c|c|c|c|c|}
\hline & $\begin{array}{l}\text { There is a } \\
\text { risk of } \\
\text { spreading } \\
\text { COVID-19 } \\
\text { to the } \\
\text { unborn } \\
\text { child if a } \\
\text { pregnant } \\
\text { woman is } \\
\text { infected } \\
\text { with } \\
\text { COVID }\end{array}$ & $\begin{array}{l}\text { For } \\
\text { mothers } \\
\text { with } \\
\text { COVID-19, } \\
\text { separation } \\
\text { of the } \\
\text { mother and } \\
\text { infant after } \\
\text { birth and } \\
\text { for up to } 14 \\
\text { days is } \\
\text { necessary } \\
\text { to prevent } \\
\text { infection of } \\
\text { the infant }\end{array}$ & $\begin{array}{l}\text { Breastfeeding } \\
\text { in mothers } \\
\text { with COVID-19 } \\
\text { is safe and } \\
\text { should be } \\
\text { encouraged }\end{array}$ & $\begin{array}{l}\text { It is safe } \\
\text { for women } \\
\text { with } \\
\text { COVID-19 } \\
\text { to deliver } \\
\text { their baby } \\
\text { via normal } \\
\text { vaginal } \\
\text { delivery }\end{array}$ & $\begin{array}{l}\text { I would be open } \\
\text { to the idea of } \\
\text { teleconferencing } \\
\text { my clinic } \\
\text { appointments to } \\
\text { minimise the } \\
\text { physical visits } \\
\text { to the hospital }\end{array}$ & $\begin{array}{l}\text { I would } \\
\text { accept } \\
\text { restriction } \\
\text { of visitors } \\
\text { during the } \\
\text { labour, } \\
\text { delivery } \\
\text { and } \\
\text { postnatal } \\
\text { stay due to } \\
\text { the COVID } \\
19 \\
\text { situation }\end{array}$ & $\begin{array}{l}\text { My plans for } \\
\text { confinement } \\
\text { practices will be } \\
\text { affected/have } \\
\text { been affected by } \\
\text { restrictions and } \\
\text { hygiene } \\
\text { recommendations }\end{array}$ \\
\hline \multirow{3}{*}{$\begin{array}{l}\text { Education } \\
\text { level } \\
\text { Primary level } \\
\text { and under } \\
\text { Post- } \\
\text { secondary } \\
\text { level }\end{array}$} & Ref & Ref & Ref & Ref & Ref & Ref & Ref \\
\hline & $\begin{array}{l}0.75 \\
(0.36,1.59)\end{array}$ & $\begin{array}{l}0.91 \\
(0.45,1.83)\end{array}$ & $\begin{array}{l}0.97 \\
(0.42,2.27)\end{array}$ & $\begin{array}{l}0.87 \\
(0.35,2.17)\end{array}$ & \multirow{2}{*}{$\begin{array}{l}1.58(0.77,3.27) \\
1.19(0.55,2.59)\end{array}$} & $\begin{array}{l}1.57 \\
(0.79,3.13)\end{array}$ & \multirow{2}{*}{$\begin{array}{l}0.77(0.39,1.53) \\
1.14(0.55,2.37)\end{array}$} \\
\hline & $\begin{array}{l}1.07 \\
(0.47,2.43)\end{array}$ & $\begin{array}{l}0.80 \\
(0.38,1.69)\end{array}$ & $\begin{array}{l}1.51 \\
(0.62,3.69)\end{array}$ & $\begin{array}{l}0.90 \\
(0.34,2.41)\end{array}$ & & $\begin{array}{l}2.57 \\
(1.21,5.45)^{*}\end{array}$ & \\
\hline \multicolumn{8}{|l|}{$\begin{array}{l}\text { Undergraduate } \\
\text { and above }\end{array}$} \\
\hline Pregnancy & Ref & Ref & Ref & Ref & Ref & Ref & Ref \\
\hline मानियुटन & $\begin{array}{l}1.18 \\
(0.55,2.57)\end{array}$ & $\begin{array}{l}0.82 \\
(0.40,1.68)\end{array}$ & $\begin{array}{l}0.44 \\
(0.19,1.00)\end{array}$ & $\begin{array}{l}0.65 \\
(0.26,1.61)\end{array}$ & \multirow{2}{*}{$\begin{array}{l}0.47(0.23,0.96) \\
0.45(0.21,0.95)\end{array}$} & $\begin{array}{l}0.58 \\
(0.27,1.23)\end{array}$ & \multirow{2}{*}{$\begin{array}{l}1.57(0.76,3.23) \\
1.62(0.76,3.41)\end{array}$} \\
\hline 2 & $\begin{array}{l}1.01 \\
(0.46,2.25)\end{array}$ & $\begin{array}{l}1.89 \\
(0.89,4.02)\end{array}$ & $0.77(0.34,1.74)$ & $\begin{array}{l}0.93 \\
(0.37,2.34)\end{array}$ & & $\begin{array}{l}0.90 \\
(0.41,1.96)\end{array}$ & \\
\hline Gravidity & Ref & Ref & Ref & Ref & Ref & Ref & Ref \\
\hline $\begin{array}{l}\text { Primigravida } \\
\text { Multigravida }\end{array}$ & $\begin{array}{l}1.3 \\
(0.85,2.42)\end{array}$ & $\begin{array}{l}1.50 \\
(0.92,2.43)\end{array}$ & $\begin{array}{l}0.42 \\
(0.23,0.75)^{*}\end{array}$ & $\begin{array}{l}0.56 \\
(0.30,1.06)\end{array}$ & $1.21(0.75,1.97)$ & $\begin{array}{l}0.83 \\
(0.51,1.34)\end{array}$ & $1.14(0.70,1.83)$ \\
\hline Age groups, & Ref & Ref & Ref & Ref & Ref & Ref & Ref \\
\hline $21-34$ & $\begin{array}{l}1.05 \\
(0.57,1.95)\end{array}$ & $\begin{array}{l}1.89 \\
(1.05,3.39)^{*}\end{array}$ & $\begin{array}{l}0.56 \\
(0.27,1.15)\end{array}$ & $\begin{array}{l}1.14 \\
(0.56,2.30)\end{array}$ & $1.0(0.56,1.79)$ & $\begin{array}{l}1.92 \\
(1.05,3.49) *\end{array}$ & $2.3(1.26,4.17)^{\star}$ \\
\hline 35 and above & & & & & & & \\
\hline Annual & Ref & Ref & Ref & Ref & Ref & Ref & Ref \\
\hline$\leq \operatorname{SGD} 10,000$ & $\begin{array}{l}1.04 \\
(0.57,1.89)\end{array}$ & $\begin{array}{l}1.95 \\
(1.11,3.40)^{*}\end{array}$ & $\begin{array}{l}0.98 \\
(0.50,1.93)\end{array}$ & $\begin{array}{l}1.03 \\
(0.48,2.23)\end{array}$ & $1.53(0.87,2.69)$ & $\begin{array}{l}0.91 \\
(0.52,1.58)\end{array}$ & $1.24(0.72,2.14)$ \\
\hline $\begin{array}{l}\text { SGD 10,001- } \\
50,000\end{array}$ & $\begin{array}{l}0.86 \\
(0.41,1.79)\end{array}$ & $\begin{array}{l}2.09 \\
(1.06,4.13)^{*}\end{array}$ & $\begin{array}{l}1.34 \\
(0.60,2.96)\end{array}$ & $\begin{array}{l}2.32 \\
(0.97,5.52)\end{array}$ & $1.27(0.6,2.52)$ & $\begin{array}{l}0.68 \\
(0.34,1.34)\end{array}$ & $1.61(0.82,3.17)$ \\
\hline$\geq \operatorname{SGD~} 50,001$ & & & & & & & \\
\hline
\end{tabular}


In this study, we explored the knowledge and expectations of perinatal and neonatal care among pregnant mothers during the current COVID-19 pandemic in Singapore. Our survey revealed that most participants were aware of the modes of SARS-CoV-2 transmission and the important transmission prevention strategies. There was significant variability identified in their understanding of the safe mode of delivery and of breastfeeding in mothers with COVID-19. Up to $60 \%$ of those surveyed were neutral or disagreed with alterations to prepandemic standards of perinatal care including the use of teleconferencing, separation of mother and infant after birth, restriction of inhospital visitors and alterations to confinement practices.

There are limited current studies reporting on the perception and expectations of perinatal care by pregnant women's during the current COVID-19 pandemic. In a recent study of the perception of the impact of COVID-19 on pregnancy and psychological impact on pregnant women, $\mathrm{Ng}$ et al highlighted the importance of timely, accurate information on the impact of COVID-19 on pregnancy and its effect on the psychological well-being of pregnant women [14]. Knowledge gaps in this regard among antenatal women was associated with increased anxiety and depression during this current pandemic. In a national cross-sectional survey conducted in Italy, Ravaldi et al [15] reported significant changes in pregnant women's expectations regarding childbirth where they expressed more fear, anxiety, pain and loneliness during this current pandemic. They also found that women with a history of psychological distress were significantly more likely to be overwhelmed by the situations caused by the COVID-19 pandemic $[15,16]$. Another study on COVID-19 awareness among pregnant women revealed that social demographic factors such as maternal age, ethnicity, frontline jobs and attendance at high-risk clinics are likely to influence the attitudes and precaution practices among of pregnant women [17]. All these studies highlight the importance of appropriate and targeted counselling to pregnant women on the potential effect of COVID-19 on pregnancy as a measure of psychological support. Our study adds to this by illustrating the potential importance of early and appropriate provision of evidencebased information to expectant mothers to reduce misinformation and moderate their expectations of perinatal and neonatal care during this current pandemic.

Much of the anxiety among pregnant women may be related to the variability of recommendations on perinatal and neonatal care that was available during the early phases of the pandemic. Most recommendations were based on expert consensus with limited evidence which were of variable and low methodological rigour $[6-8,18]$. This was likely inevitable considering the speed and magnitude of the pandemic and the rapidly evolving nature of the evidence that was available. This is evidenced by the emerging evidence on transmission of SARS-CoV-2 in utero. Recent data have confirmed the possibility of in-utero transmission, even though this is likely a very rare occurrence[19-21]. This emerging information was reflected in the majority of our survey participants agreeing that in-utero transmission of SARS-CoV-2 virus to the unborn fetus was possible. This could also possibly be due to the widespread coverage of reports of newborns diagnosed and infected with COVID-19 shortly after birth [22, 23].

Delivery room practices are important considerations in mitigating the risk of perinatal viral transmission during the current pandemic [24-27]. Emerging reports have reported SARS-CoV-2 being detected in amniotic fluid, vaginal fluid and the placenta [20, 21], highlighting the possibility of infection in utero and during delivery. Systematic review of cases reported in the literature have indicated no substantial evidence for increased transmission risk during vaginal birth[28-31]. Even so, most of the women in our cohort had expressed uncertainty regarding the optimal mode of delivery in women with COVID-19. While only $22 \%$ of women held a definitive opinion, $6 \%$ would choose to have a caesarean Section and $16 \%$ would choose to have a vaginal delivery. This is in contrast to another earlier study [17] which showed that $53 \%$ of women would opt to have a Caesarean section over a vaginal delivery if infected with SARS-CoV-2. This may be a reflection of the evolving and emerging evidence, especially that being shared in the media and by international perinatal organizations $[9,10,12]$. This uncertainty should be addressed and communicated by the clinicians, as the evidence for the safety of routine obstetric indications for delivery of pregnant women with COVID-19 accumulates [13,32].

Breastfeeding and the feeding of mother's own breast milk by women with COVID-19 have also been areas of significant contention with significant variability in the initial guidelines $[6,7,33]$. Only $22 \%$ of our study cohort would choose to actively breastfeed their infant with active COVID-19, whereas the remaining $78 \%$ were unsure or would totally avoid breastfeeding altogether. This finding is consistent to that reported by Yassa et al [34], where 50\% of the women surveyed was unsure if breastfeeding was safe during the pandemic. Breastfeeding and provision of breast milk, with its well-documented short and long-term health benefits, is an important aspect that needs to be addressed $[11,35]$. The lack of viable virus detected in reverse transcription polymerase chain reaction (RT-PCR) positive breast milk [36] and the presence of SARS-CoV-2 specific immunoglobulin A response in breast milk [37] after COVID-19 provides suggests the low likelihood of transmission via milk.

While $46.6 \%$ of participants expressed concern about the risk of contracting COVID-19 during their hospital visits, only $37 \%$ were receptive to the idea of teleconferencing as an option. Notably, women who were nulliparous were less likely to agree. Teleconferencing confers increased autonomy to the patient but would also rely heavily on patient involvement and reporting [38]. It is likely that nulliparous 
women are likely to have less confidence on self-monitoring and reporting of issues during her pregnancy. Pregnant women > 35 years were also less likely to agree to teleconferencing of hospital visits. This may be related to the perceived increased risk associated with advanced age pregnancies. With the potential need for ongoing social distancing procedures during this pandemic and beyond [39], there needs to be increased effort to improve the knowledge and increase the comfort level of pregnant women for home monitoring through the potential implementation of suitable monitoring devices and applications $[40,41]$.

Confinement is a unique postnatal practice specific to several Asian ethnicities and communities which involves the prohibition of performing certain daily tasks and the restriction of certain foods and diets. Local studies have previously shown that a negative postnatal confinement experience was a significant risk factor for postnatal depression [42]. More than half of the women surveyed reported that their confinement plans were being affected by restrictions imposed due to the current pandemic. In this regard, physicians must be aware of the importance of confinement especially in the Asian context and its significant contribution to the overall pregnancy experience. Being cognizant of the different confinement activities practiced by different ethnicities [43] and how these activities may be affected by the COVID-19 pandemic, is important to provide tailored advice to pregnant women on the postpartum care for themselves as well as for their neonates. This would also aid in improving the doctor-patient relationship and the outcomes for both pregnant women and their neonates.

Our study is limited by our relatively small sample size as well as the conduct of the survey in a single hospital in Singapore. Even so, our study cohort was recruited from the largest perinatal center on the country and the ethnic distribution is well representative of the general Singaporean population[44]. Our findings could have been influenced by selection bias as our survey was conducted on a voluntary basis and on an online platform requiring mobile devices. This could have inevitably excluded those less technologically savvy or pregnant women without mobile devices. To expand our study further, the translation of our survey into more languages and expanding the scope to neighboring South-East Asian countries to see if the findings are reproducible could be explored. In addition, a qualitative portion to the survey as well as focus group discussions could be included to elucidate the impetus behind the responses given by pregnant women.

\section{Conclusion}

Our survey revealed that majority of participants were aware of modes of transmission and the prevention strategies of SARS-CoV-2, there were however significant gaps identified in their knowledge related to the method of delivery and safety of breast feeding, along with significant variability to the agreement with alterations to the perinatal care. For best practice we recommend provision of evidence-based information early to expectant mothers by the healthcare professionals to reduce misinformation and anxiety amongst pregnant women related to the current pandemic.

\section{List Of Abbreviations}

Coronavirus disease 2019 (COVID-19)

Severe acute respiratory syndrome coronavirus 2 (SARS-CoV-2)

KK Women's and Children's Hospital (KKH)

Quick-response (QR)

Adjusted odds ratios (AOR)

Confidence intervals (Cls)

Reverse transcription polymerase chain reaction (RT-PCR)

\section{Declarations}

\section{Ethics approval and consent to participate}

Ethics approval and waiver of consent was obtained from the SingHealth Centralised Institutional Review Board (Ref No. 2020/2648). All research methods were performed with the relevant guidelines and regulations of the SingHealth Centralised Institutional Review Board. 
Not applicable

Availability of data and materials

All data generated or analysed during this study are included in this published article and its supplementary tables.

\section{Competing interests}

The authors declare that they have no competing interests.

Funding

No sources of funding were required for this research study.

\section{$\underline{\text { Contributions }}$}

CCW Lim, MSSM Goh, JY Kong and KT Yeo conceived the study, acquired the data and contributed to the analysis and drafting of the manuscript. SG Tay aided in data acquisition from survey participants and critically revised the manuscript. KH Chua, MJ Seet and M Mathur critically revised the manuscript. All authors read and approved the final manuscript.

\section{Acknowledgements}

We would like to thank all the participants of the study for completing the surveys. We would also like to acknowledge the staff members of the Specialist Obstetrics Outpatient Clinics and the Department of Neonatology at KK Women's \& Children's Hospital, Singapore for their support of this study.

\section{References}

1. World Health Organization. WHO Coronavirus Disease (COVID-19) Dashboard [https://covid19.who.int]

2. U.K. Coronavirus Third Wave, New Variant: What To Know [https://time.com/5929246/uk-coronavirus-third-wave/]

3. Onder G, Rezza G, Brusaferro S: Case-Fatality Rate and Characteristics of Patients Dying in Relation to COVID-19 in Italy. JAMA 2020, 323(18):1775-1776.

4. Allotey J, Stallings E, Bonet M, Yap M, Chatterjee S, Kew T, Debenham L, Llavall AC, Dixit A, Zhou D et al: Clinical manifestations, risk factors, and maternal and perinatal outcomes of coronavirus disease 2019 in pregnancy: living systematic review and meta-analysis. BMJ 2020, 370:m3320.

5. Raschetti R, Vivanti AJ, Vauloup-Fellous C, Loi B, Benachi A, De Luca D: Synthesis and systematic review of reported neonatal SARSCoV-2 infections. Nat Commun 2020, 11(1):5164.

6. Yeo KT, Oei JL, De Luca D, Schmolzer GM, Guaran R, Palasanthiran P, Kumar K, Buonocore G, Cheong J, Owen LS et al: Review of guidelines and recommendations from 17 countries highlights the challenges that clinicians face caring for neonates born to mothers with COVID-19. Acta Paediatr 2020.

7. Lavizzari A, Klingenberg C, Profit J, Zupancic JAF, Davis AS, Mosca F, Molloy EJ, Roehr CC, International Neonatal C-C: International comparison of guidelines for managing neonates at the early phase of the SARS-CoV-2 pandemic. Pediatr Res 2020.

8. Benski C, Di Filippo D, Taraschi G, Reich MR: Guidelines for Pregnancy Management During the COVID-19 Pandemic: A Public Health Conundrum. Int J Environ Res Public Health 2020, 17(21).

9. American College of Obstetricians and Gyneologists. COVID-19 FAQs for Obstetrician-Gynecologists, Obstetrics . [https://www.acog.org/clinical-information/physician-faqs/covid-19-faqs-for-ob-gyns-obstetrics]

10. Royal College of Obstetrics and Gynaecology. Coronavirus (COVID-19) infection and pregnancy. [https://www.rcog.org.uk/en/guidelines-research-services/guidelines/coronavirus-pregnancy/covid-19-virus-infection-andpregnancy/]

11. World Health Organization. Breastfeeding and COVID-19 [https://www.who.int/publications/i/item/10665332639]

12. World Health Organization. Coronavirus disease (COVID-19): Pregnancy and childbirth [https://www.who.int/news-room/q-adetail/coronavirus-disease-covid-19-pregnancy-and-childbirth]

13. Management of Pregnancy and Birth in Women with Coronavirus Disease (COVID-19) [https://www.ams.edu.sg/policyadvocacy/covid-19-resource-page] 
14. Ng QJ, Koh KM, Tagore S, Mathur M: Perception and Feelings of Antenatal Women during COVID-19 Pandemic: A Cross-Sectional Survey. Ann Acad Med Singap 2020, 49(8):543-552.

15. Ravaldi C, Wilson A, Ricca V, Homer C, Vannacci A: Pregnant women voice their concerns and birth expectations during the COVID-19 pandemic in Italy. Women Birth 2020.

16. Molgora S, Accordini M: Motherhood in the Time of Coronavirus: The Impact of the Pandemic Emergency on Expectant and Postpartum Women's Psychological Well-Being. Front Psychol 2020, 11:567155.

17. Lee RWK, Loy SL, Yang L, Chan JKY, Tan LK: Attitudes and precaution practices towards COVID-19 among pregnant women in Singapore: a cross-sectional survey. BMC Pregnancy Childbirth 2020, 20(1):675.

18. Chen D, Yang H, Cao Y, Cheng W, Duan T, Fan C, Fan S, Feng L, Gao Y, He F et al: Expert consensus for managing pregnant women and neonates born to mothers with suspected or confirmed novel coronavirus (COVID-19) infection. Int J Gynaecol Obstet 2020, $149(2): 130-136$.

19. Goh XL, Low YF, Ng CH, Amin Z, Ng YPM: Incidence of SARS-CoV-2 vertical transmission: a meta-analysis. Arch Dis Child Fetal Neonatal Ed 2020.

20. Kirtsman M, Diambomba Y, Poutanen SM, Malinowski AK, Vlachodimitropoulou E, Parks WT, Erdman L, Morris SK, Shah PS: Probable congenital SARS-CoV-2 infection in a neonate born to a woman with active SARS-CoV-2 infection. CMAJ 2020.

21. Vivanti AJ V-FC, Prevot S, Zupan V, Suffee C, Do Cao J, Benachi A, De Luca D: Transplacental transmission of SARS-CoV-2 infection. Nature Communications 2020, 11.

22. Baby boy infected with coronavirus in womb. In: The Guardian. Guardian News \& Media Limited 2020.

23. Baby infected with Covid-19 in the womb: Study. In: Straits Times. July 14,2020 edn; 2020.

24. Wong J, Goh QY, Tan Z, Lie SA, Tay YC, Ng SY, Soh CR: Preparing for a COVID-19 pandemic: a review of operating room outbreak response measures in a large tertiary hospital in Singapore. Can J Anaesth 2020, 67(6):732-745.

25. Oei JL BG, Petraglia F, Dani C, Serena C, Clemenza S, Mecacci F, Marlow N, Morgan AS, Modi N, Uthaya S, Hudak M, Yeo KT, Singla M, Palasanthiran P, Preisz A, Gribble K, Opie G, Perrone S: Global Pandemics, the Mother and Her Infant: Learning from the Past to Help the Future. In: Neonatology. edn. Edited by Buonocore G. BR, Weindling M. Cham, Switzerland: Springer; 2020.

26. Quek BH, Biswas A, Ee KT, Yeo CL: Newborn Resuscitation in COVID-19. Ann Acad Med Singap 2020, 49(11):909-912.

27. Chandrasekharan P, Vento M, Trevisanuto D, Partridge E, Underwood MA, Wiedeman J, Katheria A, Lakshminrusimha S: Neonatal Resuscitation and Postresuscitation Care of Infants Born to Mothers with Suspected or Confirmed SARS-CoV-2 Infection. Am J Perinatol 2020, 37(8):813-824.

28. Walker KF, O'Donoghue K, Grace N, Dorling J, Comeau JL, Li W, Thornton JG: Maternal transmission of SARS-COV-2 to the neonate, and possible routes for such transmission: a systematic review and critical analysis. BJOG 2020, 127(11):1324-1336.

29. Martínez-Perez O, Vouga M, Cruz Melguizo S, Forcen Acebal L, Panchaud A, Muñoz-Chápuli M, Baud D: Association Between Mode of Delivery Among Pregnant Women With COVID-19 and Maternal and Neonatal Outcomes in Spain. JAMA 2020, 324(3):296-299.

30. Cao D, Chen M, Peng M, Yin H, Sun G: Vaginal delivery in women with COVID-19: report of two cases. BMC Pregnancy Childbirth 2020, 20(1):580.

31. Lopian M, Kashani-Ligumsky L, Czeiger S, Cohen R, Schindler Y, Lubin D, Olteanu I, Neiger R, Lessing JB, Somekh E: Safety of vaginal delivery in women infected with COVID-19. Pediatr Neonatol 2021, 62(1):90-96.

32. Pavlidis P, Eddy K, Phung L, Farrington E, Connolly M, Lopes R, Wilson AN, Homer CSE, Vogel JP: Clinical guidelines for caring for women with COVID-19 during pregnancy, childbirth and the immediate postpartum period. Women Birth 2020.

33. Favre G, Pomar L, Qi X, Nielsen-Saines K, Musso D, Baud D: Guidelines for pregnant women with suspected SARS-CoV-2 infection. Lancet Infect Dis 2020, 20(6):652-653.

34. Yassa M, Birol P, Yirmibes C, Usta C, Haydar A, Yassa A, Sandal K, Tekin AB, Tug N: Near-term pregnant women's attitude toward, concern about and knowledge of the COVID-19 pandemic. J Matern Fetal Neonatal Med 2020, 33(22):3827-3834.

35. Jayagobi PA, Mei Chien C: Maintaining a Viable Donor Milk Supply During the SARS-CoV-2 (COVID-19) Pandemic. J Hum Lact 2020:890334420931828.

36. Chambers C, Krogstad P, Bertrand K, Contreras D, Tobin NH, Bode L, Aldrovandi G: Evaluation for SARS-CoV-2 in Breast Milk From 18 Infected Women. JAMA 2020, 324(13):1347-1348.

37. Pace RM, Williams JE, Järvinen KM, Belfort MB, Pace CD, Lackey KA, Gogel AC, Nguyen-Contant P, Kanagaiah P, Fitzgerald T et al: COVID-19 and human milk: SARS-CoV-2, antibodies, and neutralizing capacity. medRxiv 2020.

Page 12/13 
38. Tucker KL, Sheppard JP, Stevens R, Bosworth HB, Bove A, Bray EP, Earle K, George J, Godwin M, Green BB et al: Self-monitoring of blood pressure in hypertension: A systematic review and individual patient data meta-analysis. PLoS Med 2017, 14(9):e1002389.

39. Kissler SM, Tedijanto C, Goldstein E, Grad YH, Lipsitch M: Projecting the transmission dynamics of SARS-CoV-2 through the postpandemic period. Science 2020, 368(6493):860-868.

40. Kasaven LS, Saso S, Barcroft J, Yazbek J, Joash K, Stalder C, Ben Nagi J, Smith JR, Lees C, Bourne T et al: Implications for the future of Obstetrics and Gynaecology following the COVID-19 pandemic: a commentary. BJOG 2020, 127(11):1318-1323.

41. Fryer K, Delgado A, Foti T, Reid CN, Marshall J: Implementation of Obstetric Telehealth During COVID-19 and Beyond. Matern Child Health J 2020, 24(9):1104-1110.

42. Chee CY, Lee DT, Chong YS, Tan LK, Ng TP, Fones CS: Confinement and other psychosocial factors in perinatal depression: a transcultural study in Singapore. J Affect Disord 2005, 89(1-3):157-166.

43. Fok D, Aris IM, Ho J, Lim SB, Chua MC, Pang WW, Saw SM, Kwek K, Godfrey KM, Kramer MS et al: A Comparison of Practices During the Confinement Period among Chinese, Malay, and Indian Mothers in Singapore. Birth 2016, 43(3):247-254.

44. Singapore Census 2020 [https://www.singstat.gov.sg/-/media/files/publications/cop2010/census_2010_release1/cop2010sr1.pdf]

\section{Supplementary Files}

This is a list of supplementary files associated with this preprint. Click to download.

- SupplementalTable1.docx 